\title{
THE OSTRACONS OF EUROPA
}

\author{
A measure of life.
}

\section{BY KEN HINCKLEY}

$\mathrm{T}$ here was something transcendent about the pattern etched into the ice-bound Europan surface looming 53 kilometres above Ricardo Cuerta's submersible. The implacable gravity of Jupiter rewrote the great frozen palimpsest again and again, the pack ice heaved and rilled with fissures that hinted at the mysteries of the deep.

That's how he'd seen it from orbit. Now the intense blue-white glare of the spotlights seemed to be all that prevented the eternal midnight of the subsurface ocean from imploding his mind.

Particulates clouded the supercooled brine. Flurries of malformed magnesium sulphate flakes tumbled through the cones of light cast by the submersible and vanished again into the darkness. Ricardo floated, with nothing but the spotlights of the submersible and the sheer thrall of wonder between himself and the abyss. Even now, submerged within the shattered moon, he still couldn't fathom what that pattern meant.

The black chimneys of a cryovolcano rose out of the gloom like a city of diseased skyscrapers. Ricardo torqued the joystick between his thumb and forefinger, applying just enough pressure to manoeuvre the perspex tube at the end of the armature a little closer. He needed a sample, had to bring back proof - if not for the cold gaze of Science, then at least to convince himself that he wasn't confabulating wonders in the dark.

Cold sweat drenched the polypro fabric clinging to his chest. The tang of constant anxiety oiled the fatigue lines etched into his face. The slightest mistake, the tiniest unintended twitch of a muscle, and he could easily break a chimney and bring the entire tottering structure down on the submersible. If he were lucky it would breach the observation bell and he would be dead a few tenths of a second later. If he were not so fortunate, it would cripple the craft, leaving him drifting and helpless in the dark. Communication with the rest of the crew awaiting his return at the surface was impossible. There would be no final cry for help; he would never be found.

Ricardo licked the salt from his lips. It wasn't so different, really, from the brine in which the submersible was drifting at this very moment. He could have been floating in himself. It had been ten years since Rosa had died. His wife, his bride, so young. Why did he have to travel so far from home to exile himself from his own darkness?

And yet here he was, floating in the abyss.

Its gaping beak seemed to gnaw at the darkness. It lifted two thorned legs, not threatening, slowly extending them towards the spotlights on the front of the submersible. Ricardo was about to pull back when the xeno-arachnid halted. Its fronds undulated in the shadows cast by its limbs. The beak repeated its gnawing motion, then again a third time. Slowly. More deliberately. Ricardo gasped and his eyes went wide.

It was trying to tell him something. But what?

Ricardo thought he glimpsed a shimmer, an iridescence just at the limits of his perception. He fingered the toggles for the spotlights and the interior lights, flicked them off one by one, and plunged himself into abject darkness.

But as his eyes adjusted, he realized the darkness was not absolute, the darkness was not eternal.

Not at all. He had only just begun

The spotlights fell upon a brilliant white chevron in the silt-shrouded murk. At first he thought it was enormous - there was no sense of scale, nothing familiar and human by which to judge the size of objects. It winked out, then appeared again, and Ricardo realized it was close at hand, something partially occluded by the soot-black columns of the cryovolcano.

Something that moved.

He let the submersible drift. Whatever it was, he didn't want to startle it.

Slowly it came into view.

An alabaster-white carapace. Crimsontipped thorns cresting sharp-jointed legs. A hooked beak framed by feathery fronds that sculled and groped at the deep.

It was a monstrosity pried from the oilcake layers of the Burgess shale and jolted to life. The gangly and utterly alien way it moved was infused with a crawling strangeness that sent chills prickling up Ricardo's spine, across his shoulders and into the base of his brain. The words crab and spider and giant squid flashed through his mind, but of course it was none of these. He settled on xeno-arachnid, because, a man of science, he could not bring himself to call it what it was: monster.

Its fronds quivered and reached out. Probing. Curious. Angling his way. Suddenly Ricardo's mind flashed with comprehension: the creature had nothing that he recognized as eyes - but it, too, was dumbfounded with wonder. to see the light.

The xeno-arachnid's legs glowed with a ghostly bioluminescence. Its carapace grew brighter and slowly turned to face him. The legs - four of them working in unison scrabbled across the surface, wove in sombre blues and muted whites a tapestry of overlapping calligraphies that became more and more complex with each pass of its limbs.

The pattern lightning-bolted in Ricardo's mind to something he recognized, to patterns larger still. The massive pack-ice shards of Europa's frozen crust. The jumbled cuneiform of pressure ridges and rifts stamped into the icy potsherds fracturing the surface.

The rafting of the Europan surface was not random at all.

The creature was writing its story, a small fragment of the same immense narrative that was etched into the Rosetta-stone shards that circumscribed the Europan globe.

Ricardo held no proof, but he knew. The xeno-arachnid was telling him. He knew. The light in the darkness was written on its carapace. The creature was like him, a kindred spirit, an exile, and their names were scrawled upon the ostracons of Europa.

Ken Hinckley is a writer, as well as a principal scientist at Microsoft Research, where he studies human-computer interaction, including sensors, pen computing and multi-modal input. His website is kenhinckley.wordpress.com. 